\title{
Impact of dust deposition on the albedo of Vatnajökull ice cap, Iceland
}

\author{
Monika Wittmann ${ }^{1}$, Christine Dorothea Groot Zwaaftink ${ }^{2}$, Louise Steffensen Schmidt ${ }^{1}$, Sverrir Guðmundsson ${ }^{1,3}$, \\ Finnur Pálsson ${ }^{1}$, Olafur Arnalds ${ }^{4}$, Helgi Björnsson ${ }^{1}$, Throstur Thorsteinsson ${ }^{1}$, and Andreas Stohl ${ }^{2}$ \\ ${ }^{1}$ Institute of Earth Sciences, University of Iceland, Reykjavik, Iceland \\ ${ }^{2}$ NILU - Norwegian Institute for Air Research, Kjeller, Norway \\ ${ }^{3}$ Keilir, Institute of Technology, Reykjanesbær, Iceland \\ ${ }^{4}$ Agricultural University of Iceland, Hvanneyri, Iceland
}

Correspondence to: Monika Wittmann(mod3@hi.is)

Received: 30 August 2016 - Discussion started: 16 September 2016

Revised: 2 March 2017 - Accepted: 11 March 2017 - Published: 23 March 2017

\begin{abstract}
Deposition of small amounts of airborne dust on glaciers causes positive radiative forcing and enhanced melting due to the reduction of surface albedo. To study the effects of dust deposition on the mass balance of Brúarjökull, an outlet glacier of the largest ice cap in Iceland, Vatnajökull, a study of dust deposition events in the year 2012 was carried out. The dust-mobilisation module FLEXDUST was used to calculate spatio-temporally resolved dust emissions from Iceland and the dispersion model FLEXPART was used to simulate atmospheric dust dispersion and deposition. We used albedo measurements at two automatic weather stations on Brúarjökull to evaluate the dust impacts. Both stations are situated in the accumulation area of the glacier, but the lower station is close to the equilibrium line. For this site ( $\sim 1210 \mathrm{~m}$ a.s.1.), the dispersion model produced 10 major dust deposition events and a total annual deposition of $20.5 \mathrm{~g} \mathrm{~m}^{-2}$. At the station located higher on the glacier ( $\sim 1525 \mathrm{~m}$ a.s.l.), the model produced nine dust events, with one single event causing $\sim 5 \mathrm{~g} \mathrm{~m}^{-2}$ of dust deposition and a total deposition of $\sim 10 \mathrm{~g} \mathrm{~m}^{-2} \mathrm{yr}^{-1}$. The main dust source was found to be the Dyngjusandur floodplain north of Vatnajökull; northerly winds prevailed $80 \%$ of the time at the lower station when dust events occurred. In all of the simulated dust events, a corresponding albedo drop was observed at the weather stations. The influence of the dust on the albedo was estimated using the regional climate model HIRHAM5 to simulate the albedo of a clean glacier surface without dust. By comparing the measured albedo to the modelled albedo, we determine the influence of dust events on
\end{abstract}

the snow albedo and the surface energy balance. We estimate that the dust deposition caused an additional $1.1 \mathrm{~m}$ w.e. (water equivalent) of snowmelt (or $42 \%$ of the $2.8 \mathrm{~m}$ w.e. total melt) compared to a hypothetical clean glacier surface at the lower station, and $0.6 \mathrm{mw}$.e. more melt (or $38 \%$ of the $1.6 \mathrm{~m}$ w.e. melt in total) at the station located further upglacier. Our findings show that dust has a strong influence on the mass balance of glaciers in Iceland.

\section{Introduction}

The cryosphere is an important part of the global climate system. Small changes in reflected and absorbed radiation at snow or ice surfaces can have large impacts on the state of the cryosphere, and on the Earth's climate and its hydrological cycle (e.g. Budyko, 1969; Flanner et al., 2007; Painter et al., 2013). Albedo, the reflectivity of a surface, is a dominant component of the surface energy balance. The albedo of snow depends, for example, on the snow grain size, wetness and impurities in the near-surface snow layer (e.g. Wiscombe and Warren, 1980; Meinander et al., 2014). Estimation of snow albedo is important for predicting seasonal snowmelt and run-off rates and for calculating the regional and global energy budgets. Due to impurities in snow, the albedo of the snow can be reduced. This involves direct albedo reduction by the impurities but also changes in the snow grain size triggered by the impurities, especially at temperatures close to the melting point, which can strongly enhance the albedo re- 
duction (Hansen and Nazarenko, 2004; Myhre et al., 2013). Melting of the snow can further reduce the albedo if underlying ground with much lower albedo is exposed. This initiates a positive feedback loop; i.e. more snowmelt results in more absorbed radiation which in turn amplifies the melting. Even though direct global radiative forcing of mineral dust in the atmosphere is calculated as negative in the IPCC report (IPCC, 2013), regionally this depends on both the optical properties of the dust, deposited amounts and the albedo of the underlying surface. Icelandic volcanic dust (mostly from basaltic material) is darker and more absorbing than mineral dust from most other regions. It is expected to cause positive radiative forcing, due to its dark colour, the high albedo of snow and ice, and a "clumping mechanism", where fine dust impurities in snow form larger particles (DagssonWaldhauserova et al., 2015) and accelerate snowmelt. In this study, "the term radiative forcing" means the instantaneous surface-enhanced absorption due to deposited dust (Painter et al., 2007). In its effect on snow albedo, dust is somewhat similar to black carbon (Yoshida et al., 2016; Goelles et al., 2015) which has received much interest recently as a shortlived climate forcer, especially in the Arctic (e.g. Quinn et al., 2008; AMAP, 2015; Meinander et al., 2016). Other studies (e.g. Di Mauro et al., 2015; Zhao et al., 2014; He et al., 2014) have shown the impact of dust and black carbon and their effect on radiative forcing and energy balance.

Painter et al. (2007) have shown that snow cover duration in a mountain range in the United States was shortened through surface shortwave radiative forcing by deposition of desert dust. Similarly, Flanner et al. (2014) have shown that the snow albedo effect of deposited volcanic ash from an eruption in Iceland could counteract the otherwise negative radiative forcing of volcanic eruptions caused by sulfur emissions. Increased snow impurity content has an important effect on the albedo of the Greenland ice sheet. Dumont et al. (2014) estimated that the contribution of impurities to surface mass balance was at least $-27 \mathrm{Gt}^{-1}$ in recent years. A positive feedback loop is created because impurities mostly concentrate on the surface, lowering the albedo and amplifying surface melt. Seasonal snow cover duration is expected to be shortened, which can then further increase the amount of dust transported to the ice sheet and intensify the decrease in albedo (Doherty et al., 2013; Dumont et al., 2014). This will lead to an increased impact of climate change on mass balance and corresponding sea level rise of the Greenland ice sheet compared to current predictions that ignore this effect (Dumont et al., 2014).

Recent modelling studies have shown that the transport of dust from Iceland is a substantial dust source for Greenland (Groot Zwaaftink et al., 2016; Baddock et al., 2017). Furthermore, volcanic eruptions such as those in 2010 and 2011 can have a large impact (Petit et al., 2013; Davies et al., 2010).

Sources of dust in Iceland are the proglacial areas and sandy deserts which cover more than $22 \%$ of Iceland (Arnalds et al., 2001). Even though Iceland is not situated in an arid climate, it's aeolian activity is very high (Arnalds et al., 2016), due to the large area of sandur plains and frequent strong winds resulting in numerous dust events. On average, 135 dust days per year occurred in Iceland, with 101 dust days in southern Iceland and 34 dust days in northeastern Iceland including dust haze and resuspension of volcanic material. A dust day is defined as a day when at least one weather station recorded at least one dust observation (Dagsson-Waldhauserova et al., 2013, 2014). Airborne redistribution of dust has a strong influence on climate, snowmelt and Icelandic soils. Satellite images have shown that dust particles can be transported over the Atlantic and Arctic Ocean, sometimes for more than $1000 \mathrm{~km}$ (Arnalds, 2010; Baddock et al., 2017). Therefore, Icelandic dust is likely to contribute to Arctic and European air pollution and can affect the climate via dust deposition on Arctic glaciers or sea ice (Arnalds et al., 2016). Icelandic glaciers cover about $11 \%$ of the country and the focus area of this study is Vatnajökull, Iceland's largest glacier with an area of more than $8000 \mathrm{~km}^{2}$ (Fig. 1) and the largest ice cap in Europe outside the polar regions (Björnsson and Pálsson, 2008). In the year 2000 the area of the ice cap was $\sim 8100 \mathrm{~km}^{2}$ with a volume of $\sim 3100 \mathrm{~km}^{3}$. If all of this ice would melt, this would lead to a global sea level rise of $\sim 1 \mathrm{~cm}$. The average ice thickness is $380 \mathrm{~m}$, with a maximum thickness of about $950 \mathrm{~m}$. The elevation of the ice cap ranges from sea level up to $2110 \mathrm{~m}$ a.s.l. (Björnsson and Pálsson, 2008; Björnsson et al., 2013). Mass balance has been surveyed since 1991/92, with a typical mass balance of $\sim 1.5 \mathrm{~m}$ w.e. The annul balance was positive during the first years measured, but negative after 1995 (Björnsson et al., 2013), with the exception of 2014/15; the average mass balance after 1995 is $-0,65 \mathrm{~m}$ w.e.

In this study we explore what impact dust events in Iceland have on the glacier surface albedo, how often they occur and what their impact on the energy balance of glaciers in Iceland is. Therefore, dust deposition rates were calculated with a dispersion model and compared with albedo measurements on an Icelandic glacier.

\section{Methods}

\subsection{Dust transport modelling}

A recently developed scheme for dust mobilisation called FLEXDUST (Groot Zwaaftink et al., 2016) is used to estimate dust emission. The model can be applied globally, but in this study we only included dust emission from Icelandic sources. FLEXDUST produces dust emission estimates that can be imported directly into the Lagrangian particle dispersion model FLEXPART (Stohl et al., 1998, 2005) to estimate mineral dust transport, concentrations in the atmosphere and deposition on global and regional scales. FLEXDUST is based on meteorological data from the European Centre for Medium-Range Weather Forecasts (ECMWF), 


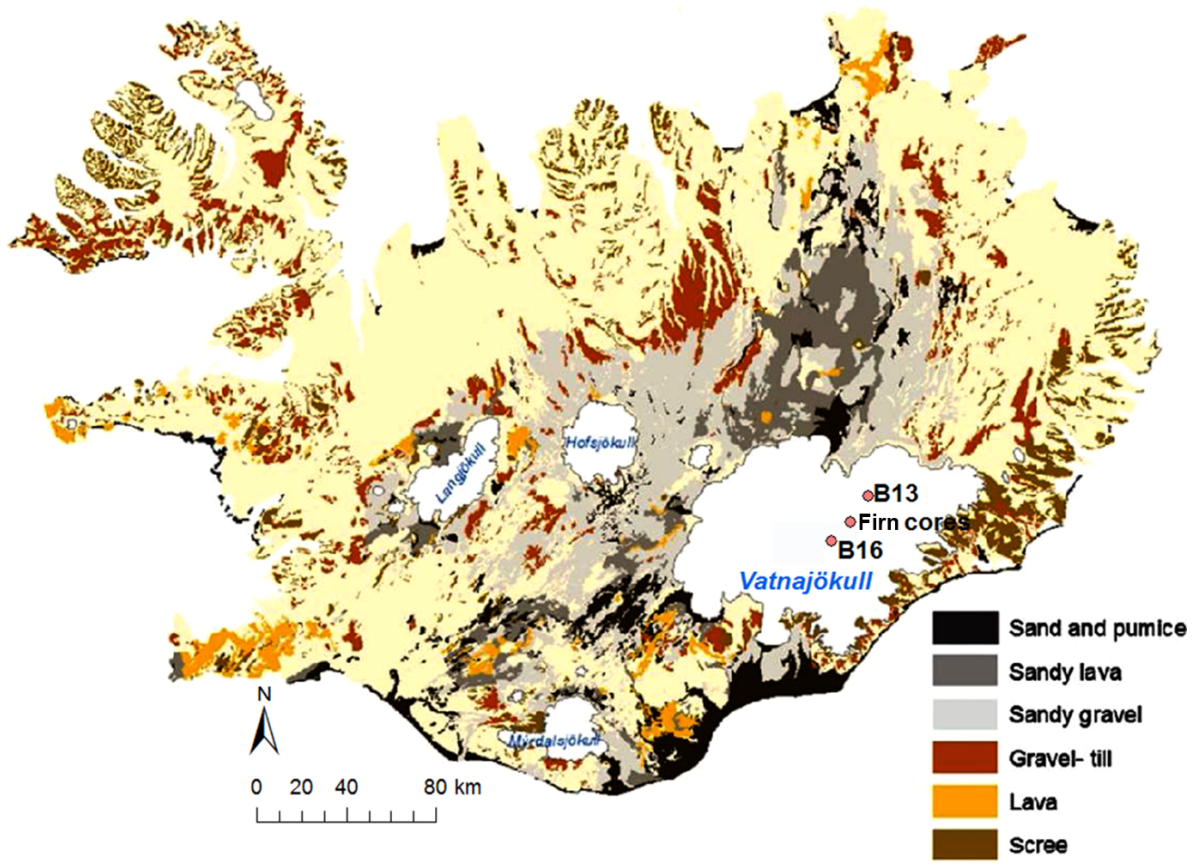

Figure 1. Iceland with glacier outlines and soil map adapted from Arnalds (2015). The two AWSs at B13 and B16 as well as the firn core drill site on Brúarjökull are highlighted.

land cover data by the Global Land Cover by National Mapping Organizations (GLCNMO) and additionally, for Iceland, a high-resolution $(\sim 1 \mathrm{arcsec})$ land cover data set that identifies sandy deserts is used (Dagsson-Waldhauserova et al., 2014; Arnalds, 2015). In FLEXDUST, dust can be emitted in regions where mineral dust is available according to the land cover data set. If snow cover exceeds a thickness of $10 \mathrm{~cm}$, dust emission is inhibited. Dust emission is initiated in regions with erodible materials if a threshold friction velocity is exceeded. Contrary to the standard version of FLEXDUST, for this study, dust mobilisation was assumed not to be influenced by soil moisture. The dust source regions in Iceland are more sediment-like than actual soils and the correct functioning of the soil moisture model is questionable for these sources, which often dry out very quickly at the surface after a precipitation event (Dagsson-Waldhauserova et al., 2014). This may enable dust mobilisation shortly after a precipitation event. The exclusion of dust emission during precipitation better describes the process of surface wetting. Therefore, in this version of FLEXDUST, dust emission is inhibited in case of precipitation but does not depend on soil moisture. We further used a combination of the erosion classes described by Arnalds (2010) and the threshold values observed by Arnalds et al. (2001) to estimate threshold friction velocity. Once mobilisation thresholds are exceeded, dust emission rates are calculated following Marticorena and Bergametti (1995). It is assumed that emitted dust particles have a size between 0.2 and $18.2 \mu \mathrm{m}$ and follow a size distribution after Kok (2011). Dust emission rates were calculated on a grid with $0.1^{\circ} \times 0.1^{\circ}$ resolution for Iceland, and with a time resolution of $3 \mathrm{~h}$.

Using the dust emission rates provided by FLEXDUST, dispersion of the dust in the atmosphere was simulated with FLEXPART version 10. Our simulations were driven with ECMWF operational analysis data with a resolution of $1^{\circ} \times 1^{\circ}$ globally and a nest over Iceland with $0.2^{\circ} \times 0.2^{\circ}$ resolution. FLEXPART simulates dispersion by transporting particles using both resolved winds and stochastic motions representing turbulence. Dust was carried in 10 size classes and was subject to both wet and dry removal. Further details about dust simulations with FLEXPART are provided by Groot Zwaaftink et al. (2016). In the current study, dust concentrations and depositions during so-called dust events, i.e. events with strong dust deposition on Vatnajökull simulated by FLEXPART, were analysed. A minimum modelled concentration of $6 \mu \mathrm{g} \mathrm{m}^{-3}$ over at least 2 days was defined as dust event. In particular, we studied simulated dust events at two automatic weather stations (AWSs) situated on Brúarjökull outlet (NE Vatnajökull, Fig. 1), namely station B13 at $\sim 1210 \mathrm{~m}$ a.s.l. and station B16 at $\sim 1525 \mathrm{~m}$ a.s.l.

\subsection{Measurements}

The year 2012 was extremely warm in the northern hemisphere. For example, in Greenland new records were set for the total glacier mass loss, surface melt extent and duration (Tedesco et al., 2013; Nghiem et al., 2012; Dumont et al., 2014). Also in Iceland, 2012 was characterised by warm tem- 
peratures, exceptionally low glacier albedo on Brúarjökull and negative glacier mass balances. Additionally, a significant number of northerly winds, likely transporting dust from Dyngjusandur towards Brúarjökull, was observed. Furthermore, no volcanic eruptions that could complicate dust deposition and albedo analysis occurred in 2012. We therefore chose this year to analyse dust events, albedo changes, glacier energy and mass balance. Besides this time series analysis in 2012, we also modelled spatial distribution of dust deposition in 2013 and will compare model results to dust amounts in snow samples from 7 October 2013. Unfortunately, such samples were not taken in 2012, but the comparison gives valuable insight into the spatial distribution that cannot be retrieved from the time series analysis. Time series of observed albedo and modelled dust deposition agreed better in 2012 than 2013.

Since 1996, AWSs B13 and B16 at Brúarjökull have been used to measure the incoming $\left(Q_{\mathrm{i}}\right)$ and outgoing $\left(Q_{\mathrm{o}}\right)$ solar radiation, incoming $\left(I_{\mathrm{i}}\right)$ and outgoing $\left(I_{\mathrm{o}}\right)$ longwave radiation, wind direction, wind speed, air temperature and relative humidity at 2 m elevation above the surface (Guðmundsson et al., 2006). Albedo is estimated from measured incoming and reflected shortwave radiation as $\alpha=Q_{\mathrm{o}} / Q_{\mathrm{i}}$. Daily albedo values were calculated as the average over $10 \mathrm{~min}$ data obtained between 13:00 and 14:00 UTC, when the solar zenith angle is smallest.

The AWS data, specifically albedo, temperature and wind, were compared with dust concentration and deposition values from FLEXPART for the measurement period in the year 2012 between days of the year (DOY) 130 and 283.

Surface snow samples, from the previous year's melted out firn layer, were collected on 7 October 2013 at 16 sites on Vatnajökull (Dragosics et al., 2016). The samples contain dust deposited at these sites during the summer of 2013. The top $\sim 8 \mathrm{~cm}$ of snow including impurities were brought to the laboratory, where they were melted, evaporated and the mass of the dust was weighed. Additionally, two $\sim 8 \mathrm{~m}$ long firn cores including dust layers from Brúarjökull (NE Vatnajökull), were drilled at B15 in 2015. The dust layers in the cores were dated depending on their depth and compared with mass balance measurements $\left(h_{\mathrm{w}} \times \rho_{\mathrm{w}}=h_{\mathrm{f}} \times \rho_{\mathrm{f}}\right.$; where $h_{\mathrm{w}}$ is mass balance given as thickness of water, $\rho_{\mathrm{w}}$ is the density of water, $h_{\mathrm{f}}$ is the thickness of a firn layer $g$ and $\rho_{\mathrm{f}}$ is the density of firn). Dust deposition rates were estimated by measuring the mass of the dust content in the annual layers, and were compared to the model results (Table 1).

\subsection{Surface energy balance calculations}

The total energy balance $(M)$ for a melting glacier surface is expressed as

$M=R+H+H_{\mathrm{p}}$,

where $R=Q \mathrm{i}(1-\alpha)+I \mathrm{i}-I \mathrm{o}$ is the net radiation obtained from the observed shortwave and longwave radiation com-
Table 1. Total dust deposition $\left[\mathrm{g} \mathrm{m}^{-2}\right.$ ] at stations on Brúarjökull in 2012 and 2013. Drill site A (Fig. 1) is situated at station B15, drill site B at $600 \mathrm{~m}$ below B15 at $1400 \mathrm{~m}$ elevation.

\begin{tabular}{lrr}
\hline 2012 & Measurements & Model \\
\hline B16 & & 10.4 \\
B13 & 20.5 \\
Firn core 2015 A & 1.7 & 9.1 \\
Firn core 2015 B & 7.9 & 8.5 \\
\hline 2013 & & \\
\hline B13 & 2.0 & 9.4 \\
\hline
\end{tabular}

ponents, and $H=H_{\mathrm{d}}+H_{1}$ is the net turbulent flux of sensible $\left(H_{\mathrm{d}}\right)$ and latent $\left(H_{1}\right)$ heat calculated from the observed temperature, humidity and wind speed within the boundary layer. A single-level model with stability factor and different roughness lengths for wind speed, temperature and humidity, described in Guðmundsson et al. (2009) was used to calculate $H_{\mathrm{d}}$ and $H_{\mathrm{l}}$. Heat supplied by precipitation $\left(H_{\mathrm{p}}\right)$ is considered negligible and the melt (ablation) $m$ is calculated as

$m=\left\{\begin{array}{l}\frac{M}{\rho_{\mathrm{w}} L_{\mathrm{f}}} ; M \geq 0 \\ 0 ; M<0\end{array}\right.$

where $L_{\mathrm{f}}$ is the latent heat of fusion $\left(L_{\mathrm{f}}=3.34 \times 10^{5} \mathrm{~J} \mathrm{~kg}^{-1}\right)$ and $\rho_{\mathrm{w}}$ the density of water $\left(1000 \mathrm{~kg} \mathrm{~m}^{-3}\right)$ (e.g. Guðmundsson et al., 2006; Hock, 2005).

Albedo is a key variable in the surface energy balance and it is used to calculate ice melting. If the energy balance is positive, this indicates an energy gain to the surface; if it is negative, it means an energy loss. The accuracy of the instruments (Kipp \& Zonen CNR1, 2000) measuring longwave and shortwave radiation fluxes at AWSs was 3\% (Guðmundsson et al., 2009).

To quantify the enhanced melt rates due to dust on the surface, the development of surface albedo for a dust-free surface must be estimated at specific locations and meteorological conditions. This albedo estimate and in situ AWS data are used to calculate the energy balance at the AWS sites. The results can be compared to energy balance calculated from only the AWS data including the observed albedo. The development of surface albedo of snow depends on meteorological processes in the surface boundary layer, the energy budget of the surface, snowfall events, etc. A regional climate model, which is forced with reanalysis data from a general circulation model at the lateral boundary and simulates the boundary layer meteorology and surface energy balance, can be used to simulate the clean surface albedo. Here we use the HIRHAM5 climate model. The HIRHAM5 model combines the dynamical core of the HIRLAM7 numerical forecasting model (Eerola, 2006) with the physical schemes from the ECHAM5 general circulation model (Roeckner et al., 2003). 
Model simulations have been validated over Greenland using AWS and ice core data (e.g. Lucas-Picher et al., 2012; Langen et al., 2015). Using the same method described in Langen et al. (2015), we run the surface scheme in HIRHAM5 by forcing it with atmospheric parameters from a previous model run. This method allows us to implement an improved albedo scheme (Nielsen-Englyst, 2015) without running the full model. This is described in more detail in the appendix and Schmidt et al. (2017).

\section{Evaluation of modelled albedo by HIRHAM5}

As there was no ice at the surface at either of the two AWSs, we allowed the modelled clean surface albedo to drop to the value of clean firn, which we assumed to be 0.55 . This value is based on the recommended value by Cuffey and Paterson (2010), but also represented in observed albedo in the years 2002, 2009 and 2014 (Fig. S1 in the Supplement). For those years, measured albedo remained mostly above 0.55 for the whole measuring period. Under dry conditions, the modelled albedo can only drop to 0.77 . The albedo of fresh snow was assumed to be 0.9 . Based on albedo measurements this value is assumed to be realistic after new snow events as seen in Fig. S1. Sometimes measured albedo values can reach high values, even above 1 , especially in autumn. This can be explained due to the high solar zenith angle, multiple reflections and instrumental error (Kipp \& Zonen CNR1, 2000).

The timescale $\tau_{\mathrm{m}}$, which determines how fast the albedo reaches its minimum value, was chosen to be 4 days, as it gives the best fit with the measurements without dropping below the measured values. In addition, this value gave the best fit when comparing it with albedo measurements for other years with higher albedo (Figs. S1 and S2) where the rate of the albedo decrease after a snowfall was realistic. Measured albedo might drop faster after a new snow event than predicted by the HIRHAM5 model because metamorphosis of fresh snow is fast at relatively high air temperatures (Oerlemans, 2001); light can also penetrate through a new thin snow layer, in which case the albedo also depends on the properties of the underlying snow layer (Wiscombe and Warren, 1980), which may also contain dust.

The AWS B16 is situated in the accumulation area, but $\mathrm{B} 13$ is close to the equilibrium line of the glacier. This means that only in some years, e.g. in 1997, 2004, 2005 and 2012 (Fig. S3), the mass balance was negative and the previous years' surface melted out at B13 and exposed firn with dust. Since 2012 was a year of very warm temperatures and negative mass balance, not only deposition during dust events influenced the albedo and energy balance. Warm and dry periods with northerly winds also increased the frequency of dust events. Due to the negative mass balance the exposed darker firn layer lowered the albedo in addition to surface dust. At station B13, between days 206 and 225, simulation values have been manually set to the minimum value of 0.55 because HIRHAM5 simulated a snowfall event, which was not observed.

\section{Results}

\subsection{Spatial distribution of dust deposition 2013 and total deposition rates 2012 and 2013}

The annual dust deposition distribution for the surface of Vatnajökull for 2013 showed a similar pattern in the model simulation and in the observations (Fig. 2). The model simulated the highest concentrations in the south-western part of Vatnajökull (Tungnaárjökull, Skaftárjökull, Síðujökull), followed by the north-western and northern parts (Brúarjökull). This distribution is due to the major dust mobilisation areas around Vatnajökull, such as Dyngjusandur, Tungná- and Skaftáörcefi (the area with severe erosion SW of Vatnajökull, Fig. 1), as well as the prevailing winds. The measurements of Dragosics et al. (2016) are shown as circles superimposed upon the modelled dust distribution in Fig. 2. The average dust deposition for the 16 measurement locations was $2 \mathrm{~g} \mathrm{~m}^{-2}$. The standard deviation of the measurements, $4 \mathrm{~g} \mathrm{~m}^{-2}$, was quite high due to one outlier with a deposition value of $16.6 \mathrm{~g} \mathrm{~m}^{-2}$ in the SW on Tungnaárjökull. The average modelled deposition for the same locations as in the measurements is $6 \mathrm{~g} \mathrm{~m}^{-2}$, with a standard deviation of $1 \mathrm{~g} \mathrm{~m}^{-2}$. Thus, the model overestimated measured dust deposition by a factor of three and generated smaller dust variability. The latter was not surprising, given the relatively coarse resolution of the model compared to the point measurements. Furthermore, variability in observed dust amounts was not only caused by the patterns of dust deposition on the glacier, but also due to windblown transport over an undulating surface, or surface melt streams washing away surface dust. Such processes were not accounted for in the modelled dust patterns. Regarding the mean concentrations, at least part of the model high bias may, in fact, be due to a location bias in the measurements. Most of the measurement locations are in the accumulation zone of the glacier. Model grid cells containing the measurement locations often extend to the glacier edges, where deposition amounts are higher. Regardless of whether the model bias can be explained or not, the comparison shows that the order of magnitude of dust deposition on Vatnajökull is captured by the model.

Table 1 gives the measured and modelled dust deposition during the years 2012 and 2013 for stations on Brúarjökull, our main area of investigation. Again, the model tended to overestimate dust deposition.

\subsection{Dust events on Brúarjökull 2012}

FLEXPART results for both dust concentrations in the air and dust deposition on the glacier surface were reported for the dust events for the year 2012 at station B13 (Table 2) and B16 (Table 3). Albedo, temperature and wind at $2 \mathrm{~m}$ elevation 
Table 2. Dust events at station B13. The modelled maximum and minimum dust concentration, the maximum simulated daily deposition, the total deposition during the event, the measured albedo change, maximum and minimum temperature and wind direction from the AWSs and the precipitation sum from the ECMWF model are reported.

\begin{tabular}{|c|c|c|c|c|c|c|c|c|c|c|c|}
\hline \multirow{3}{*}{$\begin{array}{l}\text { Event } \\
\text { Nr. }\end{array}$} & \multirow{3}{*}{ DOY } & \multirow{3}{*}{$\begin{array}{r}\text { Duration } \\
\text { [days] }\end{array}$} & \multicolumn{3}{|c|}{ Model } & \multicolumn{5}{|c|}{ AWS } & \multirow{3}{*}{$\begin{array}{r}\text { Precipitation } \\
\text { ECMWF }[\mathrm{mm}] \\
\text { sum }\end{array}$} \\
\hline & & & \multirow{2}{*}{$\begin{array}{r}\text { Concentration } \\
{\left[\mu \mathrm{g} \mathrm{m}^{-3}\right]} \\
\max \end{array}$} & \multicolumn{2}{|c|}{$\begin{array}{l}\text { Deposition } \\
{\left[\mathrm{g} \mathrm{m}^{-2}\right]}\end{array}$} & \multicolumn{2}{|c|}{$\begin{array}{l}\text { Albedo } \\
\text { change }\end{array}$} & \multicolumn{2}{|c|}{$\begin{array}{c}\text { Temperature } \\
{\left[{ }^{\circ} \mathrm{C}\right]}\end{array}$} & \multirow{2}{*}{$\begin{array}{l}\text { Wind } \\
\text { main direction }\end{array}$} & \\
\hline & & & & $\max$ & sum & $\max -\min$ & start-end & $\min$ & $\max$ & & \\
\hline 1 & 133-138 & 6 & 192.84 & 2.09 & 3.70 & 0.15 & 0.15 & -12.7 & -4.8 & $\mathrm{~N}$ & 31 \\
\hline 2 & $142-150$ & 9 & 225.12 & 0.90 & 2.48 & 0.36 & 0.36 & -2.9 & 3.4 & E, S to NW & 24 \\
\hline 3 & $157-158$ & 2 & 13.75 & 0.06 & 0.09 & 0.26 & 0.26 & -3.8 & -0.3 & NNE & 11 \\
\hline 4 & $204-210$ & 7 & 49.38 & 0.10 & 0.23 & 0.13 & 0.11 & -0.1 & 2.4 & $\mathrm{~S}$ to $\mathrm{N}$ & 19 \\
\hline 5 & 220-225 & 6 & 212.07 & 1.02 & 2.68 & 0.04 & 0.04 & 2.0 & 4.8 & SW & 0 \\
\hline 6 & 241-254 & 14 & 298.29 & 1.77 & 6.60 & 0.65 & 0.09 & -6.2 & 2.4 & SW to N,SE & 114 \\
\hline 7 & $258-261$ & 4 & 44.89 & 0.19 & 0.37 & 0.13 & 0.13 & -4.9 & -2.4 & $\mathrm{NW}$ to $\mathrm{N}$ & 14 \\
\hline 8 & $265-267$ & 3 & 49.87 & 0.21 & 0.23 & 0.30 & 0.30 & -5.1 & 1.4 & SW,SE & 48 \\
\hline 9 & $270-272$ & 3 & 67.86 & 0.29 & 0.33 & 0.34 & 0.34 & -4.0 & -1.8 & W,NE,N & 32 \\
\hline 10 & $275-278$ & 4 & 67.34 & 0.22 & 0.64 & 0.35 & 0.35 & -10.3 & -2.5 & NNE & 29 \\
\hline
\end{tabular}

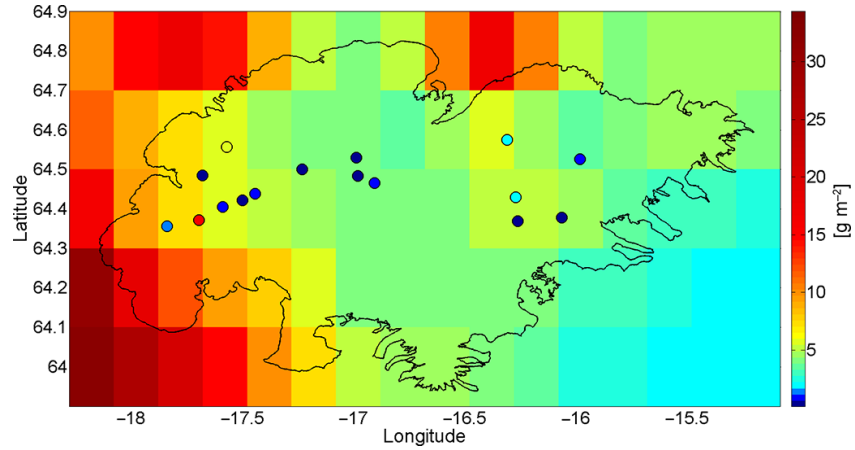

Figure 2. FLEXPART model simulation of the spatial dust distribution on Vatnajökull from 1 January to 7 October 2013, the day when the surface snow samples have been taken. The circles show the location of snow sample sites with dust deposition for the same year.

were measured at the AWSs, while precipitation data were taken from the ECMWF model. At station B13 there were 10 modelled dust events during the measuring period (9 May to 14 October 2012), and all of them were associated with an observed albedo drop during the event at the AWSs. Four events had high dust concentrations and depositions (bold in Table 2), and six smaller events occurred as well (Fig. 3). The highest deposition values were simulated during event 6 with $6.6 \mathrm{~g} \mathrm{~m}^{-2}$ of dust deposited during a period of 14 days with an albedo drop of 0.65 from the maximum to the minimum albedo value during that period. In contrast, at station B16 (Table 3$)$ the largest deposition $\left(5.2 \mathrm{~g} \mathrm{~m}^{-2}\right)$ occurred during event 1 with an albedo drop of 0.17 . Two events, one occurring during subfreezing temperatures and the other during melting temperatures, are described in detail in Sect. 3.2.1.

The albedo was almost always lower at site B13 than at site $\mathrm{B} 16$, due to the lower elevation and thus higher temperatures and increased melting at this site, probably also because of its proximity to a major dust source area (Dyngjusandur). The biggest dust events happened in spring (mid-May) and autumn (end of August and October), especially at station B16. Dust event 5 coincided with warm summer temperatures and exposure of the ablation area, where albedo at B13 reached its lowest value, 0.08 , on day 223. At the lower elevation site B13 ( $1210 \mathrm{~m}$ a.s.1.), dust deposition and concentration values during dust events were always larger than at the higher site B16 ( 1525 ma.s.1.), except for event 1 (Sect. 3.2.1). The duration of the events was also often longer at B13 than at B16. Furthermore, no dust was simulated at station B16 during event 8 (Table 3 ).

\subsubsection{Case studies}

Two dust events have been chosen for a detailed description. Event no. 1 (Fig. 4) was by far the biggest event at B16 and temperatures were below freezing all the time, and event no. 2 (Fig. 5) happened, as was often the case, during melting temperatures. The analysis of event no. 2 was supported by the availability of a clear-sky MODIS image showing the dust cloud and deposition (Fig. 6).

\section{Dust event 1}

Dust event 1 is one of four major modelled dust storms on Brúarjökull in 2012 (Fig. 4) and the only event for which total simulated dust deposition was higher at station B16 $\left(3.7 \mathrm{~g} \mathrm{~m}^{-2}\right)$ than at B13 $\left(2.6 \mathrm{~g} \mathrm{~m}^{-2}\right)$. This explains why the albedo reached a lower value between day 134 and 139 at B16 than B13, which is very atypical. During the event, albedo dropped by 0.15 from 0.9 to 0.75 at B13 (Table 2) and by 0.17 from 0.88 to 0.72 at B16. Albedo peaked on day 133 at B16 and on day 134 at B13 because of snowfall. Simulated dust deposition started on day 134 at midday and lasted un- 


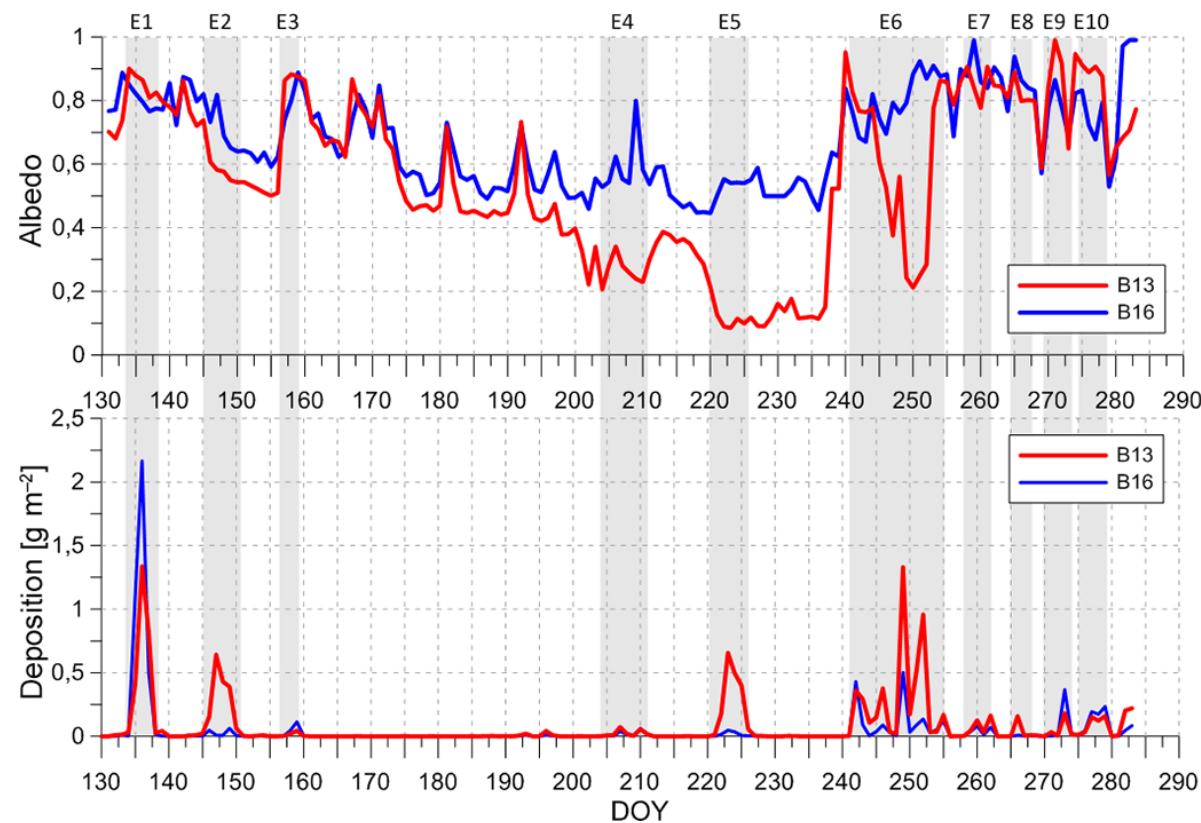

Figure 3. Upper graph: albedo measurement from the AWS at B13 in red and B16 in blue for the measurement period in 2012. Lower graph: daily dust deposition showing dust events modelled by FLEXPART. Dust events are highlighted in grey and named E1-E10.

Table 3. Same as Table 2 but for station B16.

\begin{tabular}{|c|c|c|c|c|c|c|c|c|c|c|c|}
\hline \multirow{3}{*}{$\begin{array}{l}\text { Event } \\
\text { Nr. }\end{array}$} & \multirow{3}{*}{ DOY } & \multirow{3}{*}{$\begin{array}{r}\text { Duration } \\
\text { [days] }\end{array}$} & \multicolumn{3}{|c|}{ Model } & \multicolumn{5}{|c|}{ AWS } & \multirow{3}{*}{$\begin{array}{r}\text { Precipitation } \\
\text { ECMWF }[\mathrm{mm}] \\
\text { sum }\end{array}$} \\
\hline & & & \multirow{2}{*}{$\begin{array}{r}\text { Concentration } \\
{\left[\mu \mathrm{g} \mathrm{m}^{-3}\right]} \\
\max \end{array}$} & \multicolumn{2}{|c|}{$\begin{array}{l}\text { Deposition } \\
{\left[\mathrm{g} \mathrm{m}^{-2}\right]}\end{array}$} & \multicolumn{2}{|c|}{$\begin{array}{l}\text { Albedo } \\
\text { change }\end{array}$} & \multicolumn{2}{|c|}{$\begin{array}{c}\text { Temperature } \\
{\left[{ }^{\circ} \mathrm{C}\right]}\end{array}$} & \multirow{2}{*}{$\begin{array}{l}\text { Wind } \\
\text { main direction }\end{array}$} & \\
\hline & & & & $\max$ & sum & $\max -\min$ & start-end & $\min$ & $\max$ & & \\
\hline 1 & 134-136 & 3 & 120.96 & 3.36 & 5.22 & 0.17 & 0.17 & -14.3 & -6.0 & $\mathrm{~N}$ & 25 \\
\hline 2 & $145-149$ & 6 & 19.39 & 0.05 & 0.12 & 0.28 & 0.28 & -4.1 & 2.5 & $\begin{array}{l}\text { once } \\
\text { around } \\
\text { clockwise }\end{array}$ & 2 \\
\hline 3 & $157-158$ & 2 & 15.33 & 0.12 & 0.17 & 0.27 & 0.27 & -5.1 & -0.3 & NNE & 16 \\
\hline 4 & $206-210$ & 5 & 21.14 & 0.06 & 0.15 & 0.26 & 0.04 & 2.5 & 7.6 & $\mathrm{~N}, \mathrm{SW}, \mathrm{N}$ & 4 \\
\hline 5 & $221-223$ & 3 & 15.01 & 0.07 & 0.15 & 0.01 & 0.01 & 2.2 & 2.9 & SW & 2 \\
\hline 6 & 241-254 & 14 & 71.44 & 0.66 & 2.34 & 0.25 & -0.04 & -8.4 & 0.7 & $\mathrm{~N}, \mathrm{SW}$ & 110 \\
\hline 7 & $258-259$ & 2 & 27.92 & 0.07 & 0.10 & 0.13 & 0.13 & -6.8 & -3.7 & $\mathrm{~W}$ & 4 \\
\hline 8 & no event & & & & & & & & & & \\
\hline 9 & $270-273$ & 3 & 51.31 & 0.53 & 0.55 & 0.18 & 0.18 & -5.4 & -4.7 & SW, E, N & 22 \\
\hline 10 & $275-278$ & 4 & 45.27 & 0.22 & 0.64 & 0.30 & 0.30 & -8.7 & -4.2 & $\mathrm{~N}$ & 14 \\
\hline
\end{tabular}

til day 136 (afternoon). This was the largest wet deposition event at both stations. At B13 (B16) there were $1.6 \mathrm{~g} \mathrm{~m}^{-2}$ $\left(1.3 \mathrm{~g} \mathrm{~m}^{-2}\right)$ dust deposited as dry deposition and $2.1 \mathrm{~g} \mathrm{~m}^{-2}$ $\left(3.9 \mathrm{~g} \mathrm{~m}^{-2}\right)$ as wet deposition, which at B16 was by far the largest deposition in a single event.

Near-surface dust concentration reached values of $193 \mu \mathrm{g} \mathrm{m}^{-3}$ at B13 and $121 \mu \mathrm{g} \mathrm{m}^{-3}$ at B16. Temperature decreased during the event and remained well below freezing point, excluding the possibility that melt processes were responsible for the albedo drop. This strongly supports our hypothesis that the dust deposition caused the albedo reduction.
Since dust was deposited during snowfall, the albedo drop is probably smaller than if the dust were deposited entirely by dry deposition. In fact, normally albedo increases during snowfall, so the dust deposition must have more than compensated for this effect. Wind was blowing from the north during days 134-138, with high wind speeds on day 134 and 135 (B16 $\left.16 \mathrm{~m} \mathrm{~s}^{-1}, \mathrm{~B} 1311 \mathrm{~m} \mathrm{~s}^{-1}\right)$, indicating that dust was most likely transported from Dyngjusandur. 

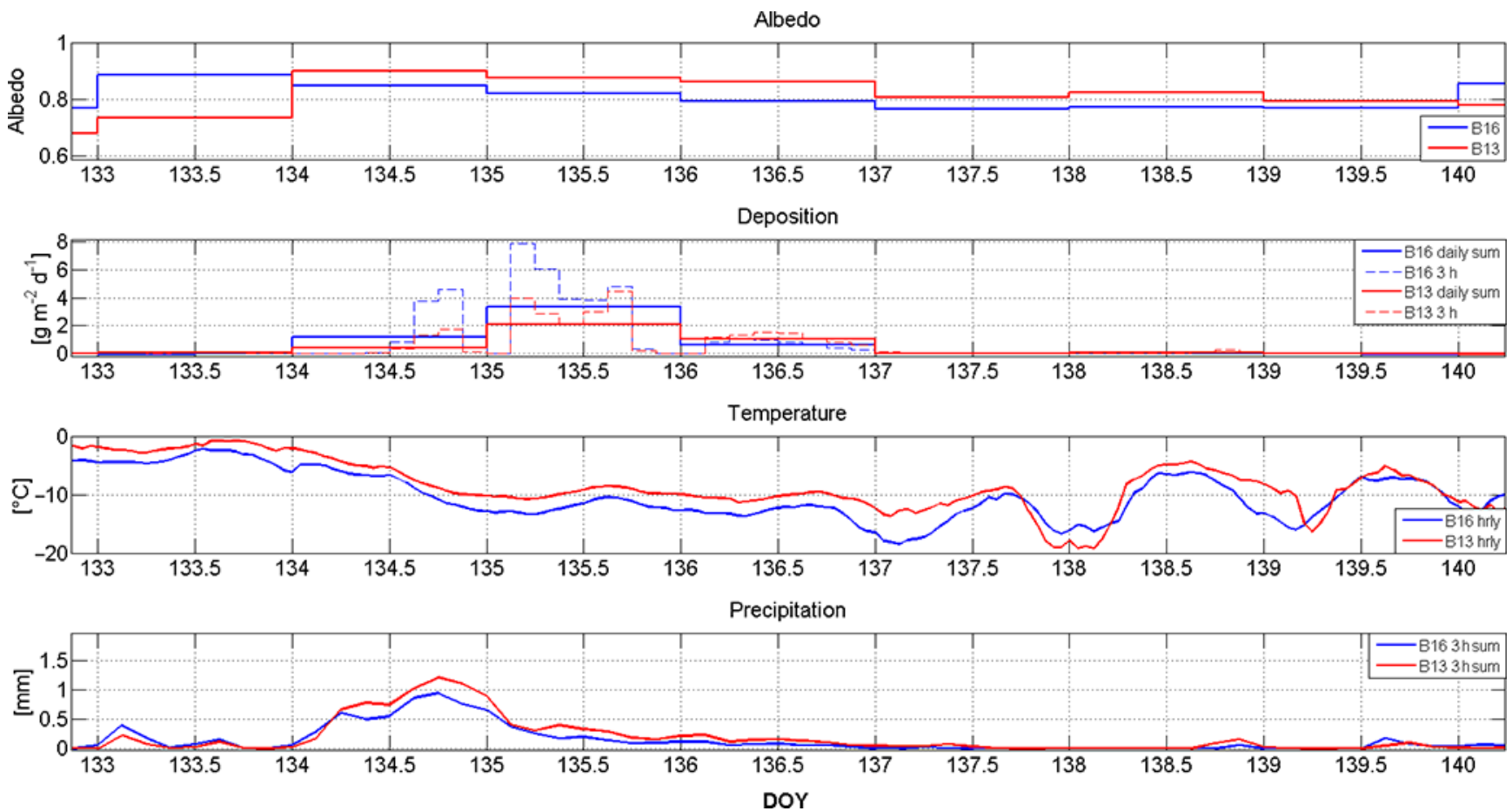

Figure 4. Observed albedo, simulated dust deposition, observed temperature and simulated precipitation dust event no. 1 at stations B16 (blue) and B13 (red). Modelled deposition is shown for $3 \mathrm{~h}$ and daily averages.

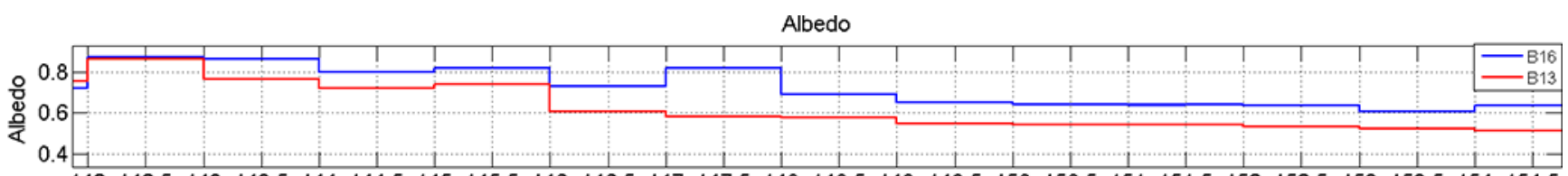

$142142.5143143 .5144144 .5145145 .5146146 .5147147 .5148148 .5149149 .5150150 .5151151 .5152 \quad 152.5153153 .5154154 .5$
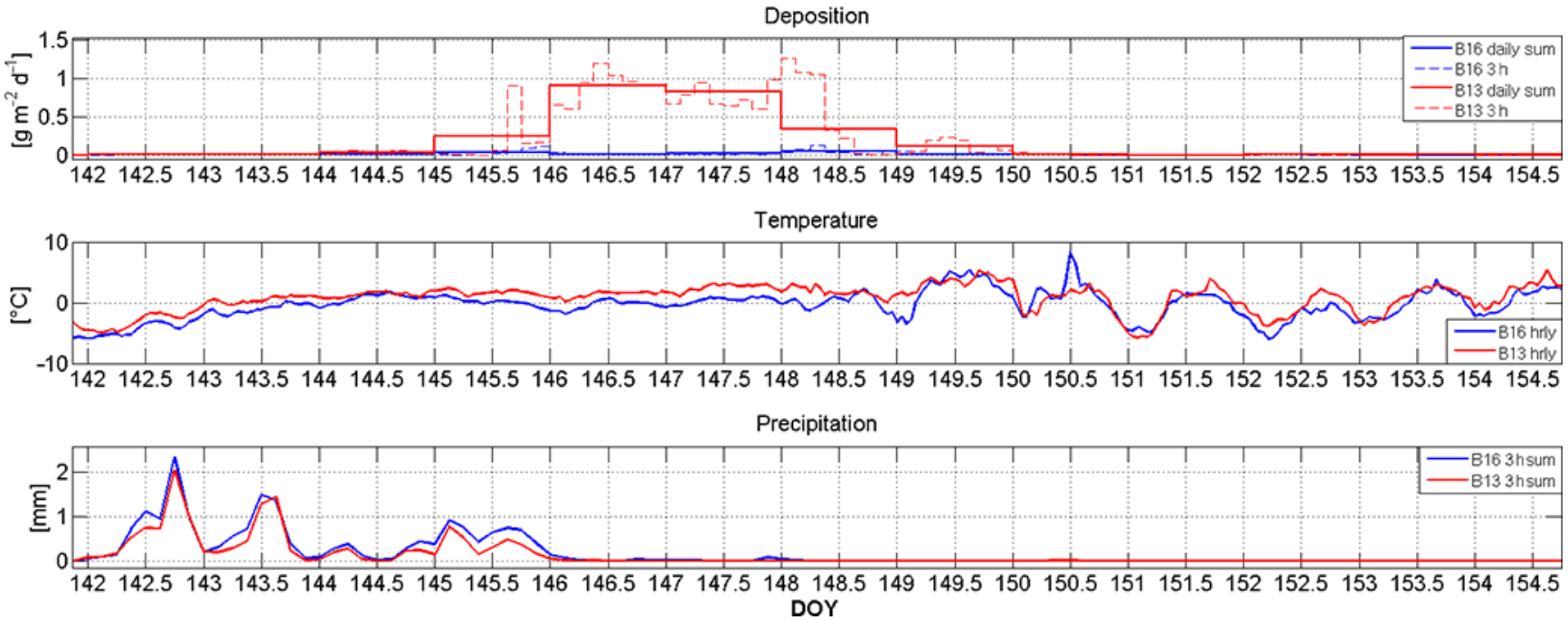

Figure 5. Observed albedo, simulated dust deposition, observed temperature and simulated precipitation dust event no. 2 at stations B16 (blue) and B13 (red). Modelled deposition is shown for $3 \mathrm{~h}$ and daily averages. 


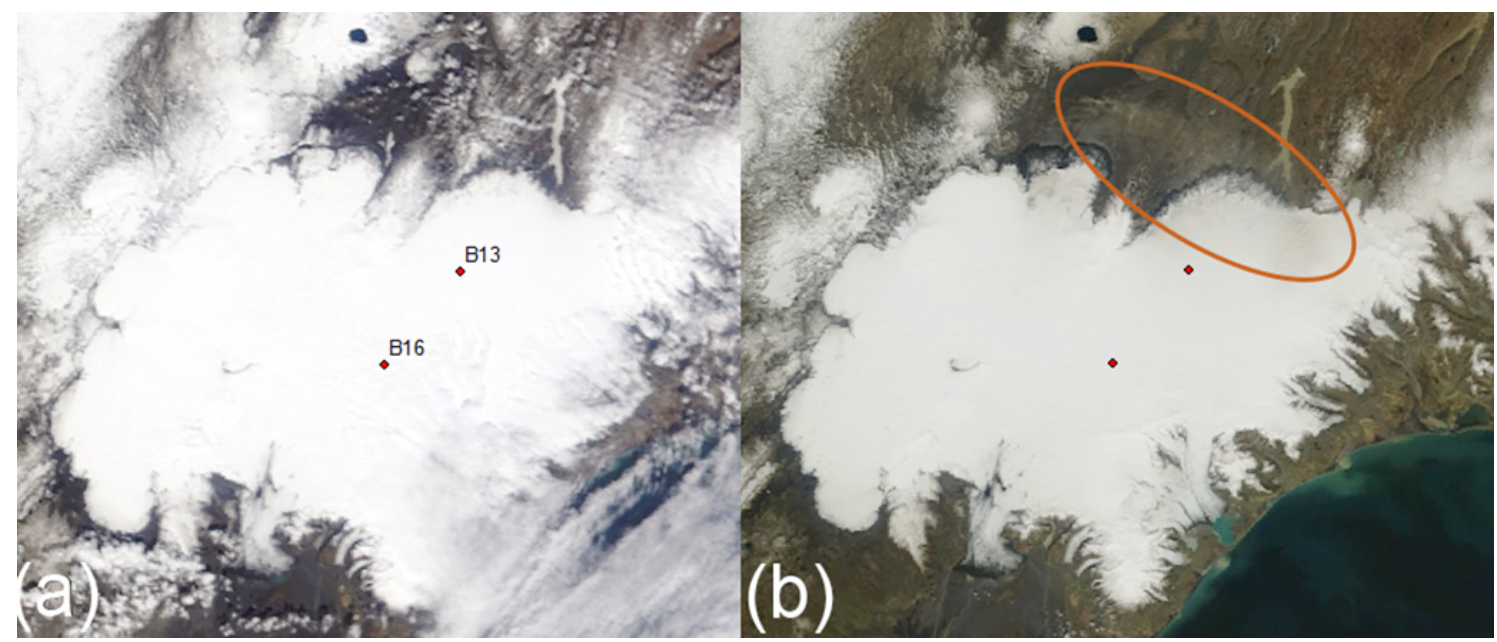

Figure 6. MODIS images of Iceland on (a) 20 May 2012 (day 141) and (b) 28 May 2012 (day 149). Notice the brownish hues (orange circle) on Brúarjökull outlet (northern Vatnajökull) after the dust event, which indicate that dust was deposited on the glacier. Image courtesy of MODIS Rapid Response System at NASA/GSFC. http://rapidfire.sci.gsfc.nasa.gov/

\section{Dust event 2}

Dust event 2 is the second largest modelled dust event in terms of dust concentration and fourth biggest in terms of total deposition at station B13 $\left(2.5 \mathrm{~g} \mathrm{~m}^{-2}\right)$ but it was much smaller at B16 $\left(0.1 \mathrm{~g} \mathrm{~m}^{-2}\right)$ and started later (day 146). Dust concentrations at B13 (B16) reached $225 \mu \mathrm{g} \mathrm{m}^{-3}$ $\left(19 \mu \mathrm{g} \mathrm{m}^{-3}\right)$. Dust deposition started in the afternoon on day 145 and albedo dropped on day 146 (from 0.73 to 0.60 ). During the whole dust event albedo dropped by 0.36 (from 0.86 to 0.5 ) at $\mathrm{B} 13$ and by 0.28 (from 0.87 to 0.59 ) at B16. Temperature rose above freezing point on day 143 and this may partly explain the albedo reduction. However, the strongest albedo reduction coincided closely with the time period of the dust deposition. In particular, notice that the albedo did not decrease significantly after the end of the deposition event, even though temperatures (at least during daytime) remained above freezing point.

Notice also that the albedo reduction was stronger at B13 than at B16, in agreement with the higher dust deposition at B13. Precipitation occurred until day 146, so mainly before dust deposition, suggesting that dust deposition was the main factor in this albedo drop. Wind was strongest on day 146 (13.6 $\mathrm{m} \mathrm{s}^{-1}$ at B13) and from SW (glacier wind), but changed to WNW up to day 149 .

Figure 6 shows a comparison between two different MODIS images (before and after the dust event). It indicates the presence of the dust plume very clearly during event 2 over the glacier, as the brownish hues are normally not present there.

\subsubsection{Average dust event at B13 in 2012}

Using the values reported in Table 2, we calculated averages to characterise an average dust event at the B13 site. On average a dust event at station B13 in 2012 lasted for 6 days, had a maximum dust concentration of $122 \mu \mathrm{g} \mathrm{m}^{-3}$ and a total deposition of $2 \mathrm{~g} \mathrm{~m}^{-2}$. Dry deposition in all cases except the first event exceeded wet deposition. This is due to the proximity of the measurement site to the source area and gravitational settling of larger particles, which dominated the removal near the source. The albedo is on average lowered by 0.18 in a dust event. This large reduction had a strong impact on the radiation and energy balance of the glacier. The average temperature during dust events was $-2^{\circ} \mathrm{C}$ (at $\sim 1210 \mathrm{~m}$ elevation) and the prevailing wind direction in $80 \%$ of the events was northerly; in $20 \%$ it is SW (the direction of the glacier wind on Brúarjökull). Average ECMWF precipitation during events was $\sim 23 \mathrm{~mm}$.

\subsection{Surface energy balance impact of dust deposition}

Deposition of dark dust particles on a glacier surface lowers the surface albedo, thus also the surface energy balance, and in general increases the energy available for melt. In order to estimate the contribution of this effect, the surface energy balance (and the surface melt from energy balance) at the two AWS sites B13 and B16 was estimated from the AWS data in 2012. To estimate the effect, the regional climate model HIRHAM5 was used to simulate a clean glacier surface for the weather conditions occurring at the AWSs B13 and B16 in 2012. The simulated clean surface albedo (black line in Fig. 7) is compared to the observed albedo including impurities (red line in Fig. 7). Generally, the model captures the measured albedo variability; however, the observed albedo 


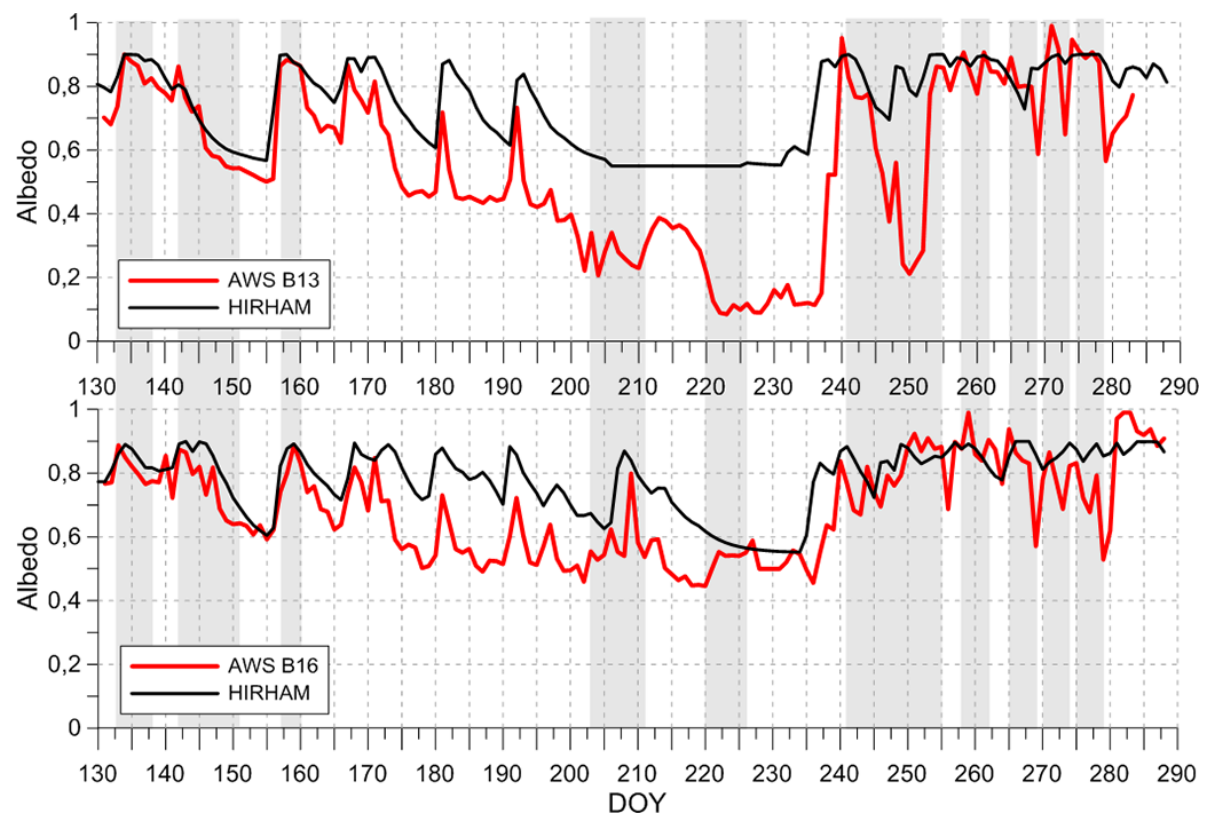

Figure 7. Measured albedo (red line) and albedo simulated with HIRHAM5 (black line) for a clean glacier surface without dust at the stations B13 (upper graph) and B16 (lower graph). Highlighted in grey are modelled dust event periods by FLEXPART.

is more variable and reaches lower values between events of snowfall. Since this is a simple model, we are not expecting the model to capture all details. The statistical fit for HIRHAM5 compared to the AWS data showed a better fit for years with higher albedos where the previous summer surface did not melt out. The average bias, taken as the difference between HIRHAM5 and AWS data, is 0.08 for the years 1997-2014, whereas for the year 2012 it is 0.18 which means an overestimate by the model. The correlation coefficient for measured and simulated albedo data for the year 2012 is 0.77 , which is higher than the average value of 0.68 for other years.

The difference between the modelled clean surface and the real surface is greater at B13 than B16. This was expected since dust concentration is much higher at the lower site B13 and snowfall is more common at the upper site B16. We also know from mass balance measurements that at B13 all the winter snow melted, exposing firn and surface dust from previous years (this happened at day $\sim 205$ ). With the addition of dust from dust events starting on days 202 and 220 (Fig. 8) the albedo values dropped very low at B 13 between days 220 and 236. The simulated energy balance did not predict the snow from the previous winter to have been melted away completely, exposing the firn layer.

High temperatures at $\mathrm{B} 13$ up to $\sim 5^{\circ} \mathrm{C}$ coincide with dust event 5 , which caused peaks in snowmelt of $8.13 \mathrm{~cm}$ w.e. day $^{-1}$ on day 222 . In the autumn, after day $\sim 240$, the energy balance was mostly negative. Low net radiation is caused by low solar radiation due to shorter days and high albedo caused by snowfall. This is accompanied by negative turbulent heat fluxes (due to air temperatures below zero and strong winds) and resulted in negative total energy, i.e. no energy available for melting in 2012.

The total summer melt at B13 in 2012 estimated from the energy balance calculated for a dust-free surface was $1.7 \mathrm{~m}$ w.e., whereas for the measured albedo the melt was estimated at $2.8 \mathrm{~m}$ w.e. From this we conclude that the melt increased by $1.1 \mathrm{~m}$ w.e., or by $\sim 60 \%$, due to dust deposition, and melting out of the dusty firn surface below. Other impurities such as black carbon were expected to be negligible (Dadic et al., 2013, Fig. 12a; Meinander et al., 2014). At the higher site, B16, $1.0 \mathrm{~m}$ w.e. of snowmelt was calculated for the modelled dust-free surface and $1.6 \mathrm{~m}$ w.e. when using the measured albedo, which results in $0.6 \mathrm{~m}$ more snowmelt caused by dust on the surface. The increase in melt is similar to that in B13, i.e. an additional $60 \%$.

\section{Discussion and conclusions}

In this paper, we have shown that dust events modelled by FLEXDUST correspond to reductions in the observed albedo at two AWS sites on Vatnajökull. This indicates that the model is able to capture the occurrence of individual dust events. Furthermore, we showed that the model captures both the observed spatial distribution of dust on the glacier as well as the order of magnitude of the total annual deposition amounts. This suggests that the model can be used for longer-term studies, to quantify the dust deposition on Vatnajökull, including its interannual variability. Table 2 shows the dust events of the year 2012 at station B13 on Brúarjökull, where in total 10 dust events occurred; four main events and 


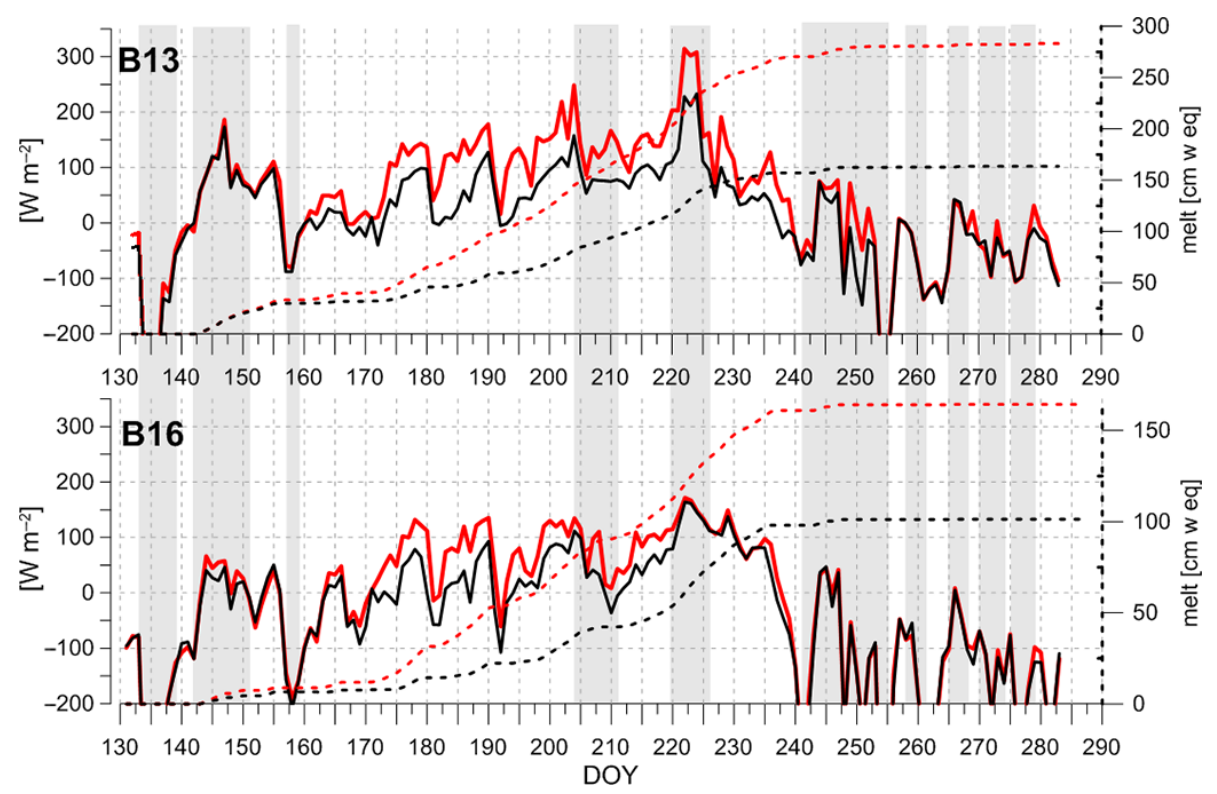

Figure 8. Measured energy balance (red line) and energy balance with simulated albedo with HIRHAM5 (black line) for a clean glacier surface without dust at the stations B13 (upper graph) and B16 (lower graph). Cumulative snowmelt is shown in dotted lines for AWSs in red and HIRHAM5 in black. Highlighted in grey are modelled dust event periods by FLEXPART.

six smaller events. The AWS measurements show a drop in albedo in connection to all dust events predicted by FLEXPART within the AWS survey period. The prevailing wind direction during dust events at site B13 is from a northerly direction, while for the whole period downslope (SW) winds dominate. The wind direction during dust events corresponds to the main dust source Dyngjusandur, north of Vatnajökull. At site B16, situated further upglacier, nine dust events occurred (Table 3) where the first dust event with $\sim 5 \mathrm{~g} \mathrm{~m}^{-2}$ of dust deposited within 3 days was by far the largest.

In Arnalds et al. (2014), the average deposition of dust on Icelandic glaciers is estimated as $\sim 400 \mathrm{~g} \mathrm{~m}^{-2} \mathrm{yr}^{-1}$ which seems to be an overestimate in the light of results presented here. Their estimate includes periodic tephra deposition and large dust events based on a country average and it does not adequately account for topographic differences and that much of the glacial areas are upwind for dry winds from the main dust sources at the glacial margins. With FLEXPART, we calculated much lower annual deposition rates for Vatnajökull and its surroundings in 2013 (Fig. 2), up to $34 \mathrm{~g} \mathrm{~m}^{-2}$ in the $\mathrm{SW}$ of the glacier. Moreover, modelled values for dust deposition rates on Brúarjökull of $20 \mathrm{~g} \mathrm{~m}^{-2}$ (B13) and $10 \mathrm{~g} \mathrm{~m}^{-2}$ (B16) for 2012 were much lower.

Firn core B drilled on Brúarjökull showed a dust layer of $\sim 8 \mathrm{~g} \mathrm{~m}^{-2}$ for 2012 (Table 1), in very good agreement with the simulated dust of $8.5 \mathrm{~g} \mathrm{~m}^{-2}$. At firn core A, drilled in the immediate vicinity of core $\mathrm{B}$, observed deposition rate was much smaller $\left(1.7 \mathrm{~g} \mathrm{~m}^{-2}\right)$, showing the large spatial variability and consequent uncertainty in comparing point measurements to model simulations. We thus consider the model re- sults satisfactory if they are of the same order of magnitude as observed dust amounts in ice cores or snow samples.

To estimate the impact of dust on the surface energy balance and melt rates, the regional climate model HIRHAM5 was used to simulate the surface albedo for a dust-free (i.e. clean) snow surface during the summer 2012. The surface energy balance (and melt rate) was calculated using the simulated albedo and the albedo observed from the AWS data. At the lower site, B13, the difference between dust-free and real surface is $1.1 \mathrm{~m}$ w.e. more snowmelt $(1.7 \mathrm{~m}$ w.e. snowmelt for the clean surface and $2.8 \mathrm{~m}$ w.e. for the real surface). This does not only include dust events lowering surface albedo, but also dust and tephra that were deposited during previous years, melting out from below. At the upper site B16 the difference results in $0.6 \mathrm{~m}$ more snowmelt $(1.0 \mathrm{~m}$ w.e. for the clean surface and $1.6 \mathrm{~m}$ w.e. for the AWSs). Since B16 is situated in the accumulation area, no dust is expected to melt out from below. It cannot be excluded that small amounts of organic material or black carbon are deposited on the snow surface and influence albedo, but from in situ investigations this has not been observed in this area.

The year 2012 was a year of intensive summer melt. At site B13 on Vatnajökull the measured summer mass balance was $2.3 \mathrm{~m}$ w.e. mass loss, which means $0.5 \mathrm{~m}$ more mass loss than the average since 1993 (1.7 m w.e.). Summer mass balance measurements on Vatnajökull show $2.3 \mathrm{~m}$ w.e. of total mass loss at B13 which is $0.5 \mathrm{~m}$ less melt compared to calculated energy balance converted into snowmelt ( $2.8 \mathrm{~m}$ w.e.). Most of these differences are assigned to summer snowfall that melts, and was not captured with the mass balance measurements. 
Oerlemans et al. (2009) reported that decreased albedo at Vadret da Morteratsch glacier caused an additional removal of about $3.5 \mathrm{~m}$ of ice for the 4-year period 2003-06. This means $0.9 \mathrm{~m}$ more melt on average per year. Gabbi et al. (2015) compared a glacier surface with deposits of black carbon and Saharan dust to pure snow conditions for a 100year period (1914-2014). They found that the mean annual albedo decreased by $0.04-0.06$; therefore the mean annual mass balance was reduced by about $28-49 \mathrm{~cm}$. These alpine melt rates due to impurities are in the same order of magnitude as our results.

Albedo comparisons for other years (Fig. S3) have shown very low albedo values for the years 1997, 2004, 2005 and 2012. The surface dirt causing the low albedo in 1997 is related to the Gjálp eruption in 1996, and the following huge jökulhlaup with deposition of fine-grained particles on the Skeiðarársandur sandur plain. This was a vast source of dust in the dry and warm 1997 summer. The low albedo in 2005 and 2012 are most likely also related to the 2004 and 2011 Grímsvötn eruptions (e.g. Guðmundsson et al., 2006; Möller et al., 2013.) In 2004 increased melt rates due to high winddriven turbulent heat fluxes at the end of July, followed by exceptionally warm and sunny weather in August, sped up the melting of old firn (Guðmundsson et al., 2006).

The results in this paper show the impact of positive radiative forcing on snowmelt of Icelandic glaciers caused by deposition of dust that strongly enhances absorption of light. The duration of dust radiative effects on glacier surfaces is extended compared to purely atmospheric effects because of the short lifetime of dust in the atmosphere.

Data availability. The data are not publicly available.

\section{The Supplement related to this article is available online at doi:10.5194/tc-11-741-2017-supplement.}

Competing interests. The authors declare that they have no conflict of interest.

Acknowledgements. The study described in this manuscript was supported by NordForsk as part of the two Nordic Centres of Excellence Cryosphere-Atmosphere Interactions in a Changing Arctic climate (CRAICC), and eScience Tools for Investigating Climate Change (eSTICC). Part of this work was supported by the Centre of Excellence in Atmospheric Science funded by the Finnish Academy of Sciences Excellence (project no. 272041), by the Finnish Academy of Sciences project A4 (contract 254195). Data from in situ mass balance surveys and on glacier automatic weather stations are from joint projects of the National Power Company and the Glaciology group of the Institute of Earth Science, University of Iceland. C. Groot Zwaaftink was also funded by the Swiss National Science Foundation SNF (155294), and Louise Steffensen-Schmidt, Finnur Pálsson and Sverrir Guðmunds- son by the Icelandic Research Fund (project SAMAR) and the National Power Company of Iceland. Ólafur Arnalds was in part funded by Icelandic Research Fund (grant no. 152248-051)

Edited by: S. M. Noe

Reviewed by: two anonymous referees

\section{References}

AMAP Assessment 2015: Black carbon and ozone as Arctic climate forcers. Arctic Monitoring and Assessment Programme (AMAP), Oslo, Norway, vii +, 116 pp., 2015.

Arnalds, O.: Dust sources and deposition of aeolian materials in Iceland, Icelandic Agricultural Sciences, 23, 3-21, 2010.

Arnalds, O.: The soils of Iceland, Springer, Dordrecht, the Netherlands, 160 pp., 2015.

Arnalds, O., Gisladottir, F. O., and Sigurjonsson, H.: Sandy deserts of Iceland: an overview, J. Arid Environ., 47, 359-371, 2001.

Arnalds, O., Olafsson, H., and Dagsson-Waldhauserova, P.: Quantification of iron-rich volcanogenic dust emissions and deposition over the ocean from Icelandic dust sources, Biogeosciences, 11, 6623-6632, doi:10.5194/bg-11-6623-2014, 2014.

Arnalds, O., Dagsson-Waldhauserova, P., and Olafsson, H.: The Icelandic volcanic aeolian environment: Processes and impacts - A review, Aeolian Research, 20, 176-195, 2016.

Baddock, M. C., Mockford, T., Bullard, J. E., and Thorsteinsson, T.: Pathways of high-latitude dust in the North Atlantic, Earth Planet. Sc. Lett., 459, 170-182, 2017.

Björnsson, H. and Pálsson, F.: Icelandic glaciers, Jökull, 58, 365386, 2008.

Björnsson, H., Pálsson, F., Gudmundsson, S., Magnússon, E., Adalgeirsdóttir, G., Jóhannesson, T., Berthier, E., Sigurdsson, O., and Thorsteinsson, T.: Contribution of Icelandic ice caps to sea level rise: Trends and variability since the Little Ice Age, Geophys. Res. Lett., 40, 1-5, doi:10.1002/grl.50278, 2013.

Budyko, M. I.: The effect of solar radiation variations on the climate of the earth, Tellus, 21, 611-619, 1969.

Cuffey, K. M. and Paterson, W. S. B.: The physics of glaciers, 693 pp., Academic Press, 2010.

Dadic, R., Mullen, P. C., Schneebeli, M., Brandt, R. E., and Warren, S. G.: Effects of bubbles, cracks, and volcanic tephra on the spectral albedo of bare ice near the Transantarctic Mountains: Implications for sea glaciers on Snowball Earth, J. Geophys. Res.Earth, 118, 1658-1676, 2013.

Dagsson-Waldhauserova, P., Arnalds, O., and Olafsson, H.: Longterm frequency and characteristics of dust storm events in Northeast Iceland (1949-2011), Atmos. Environ., 77, 117-127, 2013.

Dagsson-Waldhauserova, P., Arnalds, O., Olafsson, H., Skrabalova, L., Sigurdardottir, G. M., Branis, M., Hladil, J., Skala, R., Navratil, T., Chadimova, L., Von Lowis of Menar, S., Throsteinsson, T., Krage Carlsen, H., and Jonsdottir, I.: Physical properties of suspended dust during moist and low wind conditions in Iceland, Icelandic Agricultural Sciences, 27, 25-39, 2014.

Dagsson-Waldhauserova, P., Arnalds, O., Olafsson, H., Hladil, J., Skala, R., Navratil, T., Chadimova, L., and Meinander, O.: Snow-dust storm: unique case study from Iceland, 67 March 2013, Aeolian Research, 16, 69-74, 2015. 
Davies, S. M., Larsen, G., Wastegård, S., Turney, C. S., Hall, V. A., Coyle, L., and Thordarson, T.: Widespread dispersal of Icelandic tephra: how does the Eyjafjöll eruption of 2010 compare to past Icelandic events?, J. Quaternary Sci., 25, 605-611, 2010.

Di Mauro, B., Fava, F., Ferrero, L., Garzonio, R., Baccolo, G., Delmonte, B., and Colombo, R.: Mineral dust impact on snow radiative properties in the European Alps combining ground, UAV, and satellite observations, J. Geophys. Res.-Atmos., 120, 60806097, 2015.

Doherty, S. J., Grenfell, T. C., Forsström, S., Hegg, D. L., Brandt, R. E., and Warren, S. G.: Observed vertical redistribution of black carbon and other insoluble light-absorbing particles in melting snow, J. Geophys. Res.-Atmos., 118, 5553-5569, 2013.

Dragosics, M., Meinander, O., Jónsdóttir, T., Dürig, T., De Leeuw, G., Pálsson, F., Dagsson-Waldhauserová, P., and Thorsteinsson, T.: Insulation effects of Icelandic dust and volcanic ash on snow and ice, Arab. J. Geosci., 9, 1-10, 2016.

Dumont, M., Brun, E., Picard, G., Michou, M., Libois, Q., Petit, J. R., Morin, S., and Josse, B.: Contribution of light-absorbing impurities in snow to Greenland/'s darkening since 2009, Nat. Geosci., 7, 509-512, 2014.

Eerola, K.: About the performance of HIRLAM version 7.0, HIRLAM Newsletter, 51, 93-102, 2006.

Flanner, M. G., Zender, C. S., Randerson, J. T., and Rasch, P. J.: Present-day climate forcing and response from black carbon in snow, J. Geophys. Res.-Atmos., 112, D11202, doi:10.1029/2006JD008003, 2007.

Flanner, M. G., Gardner, A. S., Eckhardt, S., Stohl, A., and Perket, J.: Aerosol radiative forcing from the 2010 Eyjafjallajökull volcanic eruptions, J. Geophys. Res., 119, 9481-9491, doi:10.1002/2014JD021977, 2014.

Gabbi, J., Huss, M., Bauder, A., Cao, F., and Schwikowski, M.: The impact of Saharan dust and black carbon on albedo and long-term mass balance of an Alpine glacier, The Cryosphere, 9, 13851400, doi:10.5194/tc-9-1385-2015, 2015.

Goelles, T., Bøggild, C. E., and Greve, R.: Ice sheet mass loss caused by dust and black carbon accumulation, The Cryosphere, 9, 1845-1856, doi:10.5194/tc-9-1845-2015, 2015.

Groot Zwaaftink, C. D., Grythe, H., Skov, H., and Stohl, A.: Substantial contribution of northern high-latitude sources to mineral dust in the Arctic, J. Geophys. Res.-Atmos., 121, 13678-13697, doi:10.1002/2016JD025482, 2016.

Guðmundsson, S., Björnsson, H., Pálsson, F., and Haraldsson, H. H.: Energy balance of Brúarjökull and circumstances leading to the August 2004 floods in the river Jökla, N-Vatnajökull, Jökull, $55,1-18,2006$.

Guðmundsson, S., Björnsson, H., Pálsson, F., and Haraldsson, H. H.: Comparison of energy balance and degree-day models of summer ablation on the Langjökull ice cap, SW-Iceland, Jökull, $59,1-18,2009$.

Hansen, J. and Nazarenko, L.: Soot climate forcing via snow and ice albedos, P. Natl. Acad. Sci. USA, 101, 423-428, 2004.

He, C., Li, Q. B., Liou, K. N., Takano, Y., Gu, Y., Qi, L., Mao, Y. H., and Leung, L. R.: Black carbon radiative forcing over the Tibetan Plateau, Geophys. Res. Lett., 41, 7806-7813, doi:10.1002/2014g1062191, 2014.

Hock, R.: Glacier melt: a review of processes and their modelling, Prog. Phys. Geog., 29, 362-391, 2005.
IPCC: Climate change 2013: The physical science basis, in: Working Group I, Contribution to the IPCC 5th Assessment Report summary for policy makers, edited by: Stocker, T. F., Quin, D., Plattner, G., Tignor, M. M. B., Allen, S., Boschung, J., Nauels, A., Xia, Y., Bex, V., Midgley, P., 2013.

Kipp \& Zonen Instruction Manual for Pyranometer/Albedometer CM11 and CM14, available at: http://www.kippzonen.com (last access: 30 August 2016), 2000.

Kok, J. F.: A scaling theory for the size distribution of emitted dust aerosols suggests climate models underestimate the size of the global dust cycle, P. Natl. Acad. Sci., 108, 1016-1021, 2011.

Langen, P. L., Mottram, R. H., Christensen, J. H., Boberg, F., Rodehacke, C. B., Stendel, M., van As, D., Ahlstrøm, A. P., Mortensen, J., Rysgaard, S., Petersen, D., Svendsen, K. H. , Aðalgeirsdóttir, G., and Cappelen, J.: Quantifying Energy and Mass Fluxes Controlling Godthåbsfjord Freshwater Input in a 5km Simulation (1991-2012), J. Climate, 28, 3694-3713, 2015.

Lucas-Picher, P., Wulff-Nielsen, M., Christensen, J. H., Adalgeirsdóttir, G., Mottram, R. H., and Simonsen, S. B.: Very high resolution regional climate model simulations over Greenland: Identifying added value, J. Geophys. Res., 121, 13678-13697 , 2012.

Marticorena, B. and Bergametti, G.: Modeling the atmospheric dust cycle: 1. Design of a soil-derived dust emission scheme, J. Geophys. Res.-Atmos., 100, 16415-16430, 1995.

Meinander, O., Kontu, A., Virkkula, A., Arola, A., Backman, L., Dagsson-Waldhauserová, P., Järvinen, O., Manninen, T., Svensson, J., de Leeuw, G., and Leppäranta, M.: Brief communication: Light-absorbing impurities can reduce the density of melting snow, The Cryosphere, 8, 991-995, doi:10.5194/tc-8-9912014, 2014.

Meinander, O., Dagsson-Waldhauserova, P., and Arnalds, O.: Icelandic volcanic dust can have a significant influence on the cryosphere in Greenland and elsewhere, Polar Research, 35, 1751-8369, doi:10.3402/polar.v35.31313, 2016.

Möller, R., Möller, M., Björnsson, H., Guðmundsson, S., Pálsson, F., Oddsson, B., Kukla, P. A., and Schneider, C.: MODIS-derived albedo changes of Vatnajökull (Iceland) due to tephradeposition from the 2004 Grímsvötn eruption, Int. J. Appl. Earth Obs., 26, 256-269, 2013.

Myhre, G., Shindell, D., Bréon, F. M., Collins, W., Fuglestvedt, J., Huang, J., Koch, D., Lamarque, J.-F., Lee, D., Mendoza, B., Nakajima, T., Robock, A., Stephens, G., Takemura, T., and Zhang, H.: Anthropogenic and Natural Radiative Forcing, in: Climate Change 2013: The Physical Science Basis, Contribution of Working Group 1 to the Fifth Assessment Report of the Intergovernmental Panel on Climate Change, Table, 8, 714, 2013.

Nghiem, S. V., Hall, D. K., Mote, T. L., Tedesco, M., Albert, M. R., Keegan, K., Shuman, C. A., DiGirolamo, N. E., and Neumann, G.: The extreme melt across the Greenland ice sheet in 2012, Geophys. Res. Lett., 39, L20502, doi:10.1029/2012GL053611, 2012.

Nielsen-Englyst, P.: Impact of albedo parameterizations on surface mass balance and runoff on the Greenland Ice Sheet, Master's thesis University of Copenhagen, unpublished, 2015.

Oerlemans, J.: Glaciers and climate change, CRC Press, 2001.

Oerlemans, J., Giesen, R. H., and Van den Broeke, M. R.: Retreating alpine glaciers: increased melt rates due to accumulation of dust (Vadret da Morteratsch, Switzerland), J. Glaciol., 55, 729-736, 2009. 
Painter, T. H., Barrett, A. P., Landry, C. C., Neff, J. C., Cassidy, M. P., Lawrence, C. R., McBride, K. E., and Farmer, G. L.: Impact of disturbed desert soils on duration of mountain snow cover, Geophys. Res. Lett., 34, L12502, doi:10.1029/2007GL030284, 2007.

Painter, T. H., Flanner, M. G., Kaser, G., Marzeion, B., VanCuren, R. A., and Abdalati, W.: End of the Little Ice Age in the Alps forced by industrial black carbon, P. Natl. Acad. Sci., 110, 15216-15221, 2013.

Petit, J. R., Wegner, A., Narsici, B., Svensson, A., Bigler, M., and Steffensen, J. P.: The NEEM record of aeolian dust: contributions from Coulter counter measurements, in: EGU General Assembly Conference Abstracts, 15, p. 6255, 2013.

Quinn, P. K., Bates, T. S., Baum, E., Doubleday, N., Fiore, A. M., Flanner, M., Fridlind, A., Garrett, T. J., Koch, D., Menon, S., Shindell, D., Stohl, A., and Warren, S. G.: Short-lived pollutants in the Arctic: their climate impact and possible mitigation strategies, Atmos. Chem. Phys., 8, 1723-1735, doi:10.5194/acp8-1723-2008, 2008.

Roeckner, E., Bäuml, G., Bonaventura, L., Brokopf, R., Esch, M., Giorgetta, M., Hagemann, S., Kirchner, I., Kornblueh, L., Manzini, E., Rhodin, A., Schlese, U., Schulzweida, U., and Tompkins, A.: The atmospheric general circulation model ECHAM 5 PART I: Model description, Technical Report 349, Report/MPI für Meteorologie, 2003.

Schmidt, L. S., Aðalgeirsdóttir, G., Guðmundsson, S., Langen, P. L., Pálsson, F., Mottram, R., Gascoin, S., and Björnsson, H.: The importance of accurate glacier albedo for estimates of surface mass balance on Vatnajökull: Evaluating the surface energy budget in a Regional Climate Model with automatic weather station observations, The Cryosphere Discuss., doi:10.5194/tc-2017-14, in review, 2017.
Stohl, A., Hittenberger, M., and Wotawa, G.: Validation of the Lagrangian particle dispersion model FLEXPART against largescale tracer experiment data, Atmos. Environ., 32, 4245-4264, 1998.

Stohl, A., Forster, C., Frank, A., Seibert, P., and Wotawa, G.: Technical note: The Lagrangian particle dispersion model FLEXPART version 6.2, Atmos. Chem. Phys., 5, 2461-2474, doi:10.5194/acp-5-2461-2005, 2005.

Tedesco, M., Fettweis, X., Mote, T., Wahr, J., Alexander, P., Box, J. E., and Wouters, B.: Evidence and analysis of 2012 Greenland records from spaceborne observations, a regional climate model and reanalysis data, The Cryosphere, 7, 615-630, doi:10.5194/tc7-615-2013, 2013.

Wiscombe, W. J. and Warren, S. G.: A model for the spectral albedo of snow. I: Pure snow, J. Atmos. Sci., 37, 2712-2733, 1980.

Yoshida, A., Moteki, N., Ohata, S., Mori, T., Tada, R., Dagsson-Waldhauserová, P., and Kondo, Y.: Detection of light-absorbing iron oxide particles using a modified singleparticle soot photometer, Aerosol Sci. Tech., 50, 1-4, doi:10.1080/02786826.2016.1146402, 2016.

Zhao, C., Hu, Z., Qian, Y., Ruby Leung, L., Huang, J., Huang, M., Jin, J., Flanner, M. G., Zhang, R., Wang, H., Yan, H., Lu, Z., and Streets, D. G.: Simulating black carbon and dust and their radiative forcing in seasonal snow: a case study over North China with field campaign measurements, Atmos. Chem. Phys., 14, 1147511491, doi:10.5194/acp-14-11475-2014, 2014. 